\title{
The Willy Wagtail Tale: Knowledge Management and E-Learning Enriching Multiliteracies in the Early Years
}

\author{
Sandra Hesterman* \\ School of Education, Murdoch University, Perth, Western Australia \\ E-mail: s.hesterman@murdoch.edu.au \\ *Corresponding author
}

\begin{abstract}
While our multimedia world, with rapid advances in technologies, now challenges educators to consider new pedagogies that expand cultural and linguistic diversity, the potential for information and communication technologies (ICT) to support literacy learning in the early years remains a seriously under-researched area. There is an urgency to address a range of questions raised by teacher practitioners such as what new literacies will look like in their programs, how ICT can be used to learn in new ways, and which pedagogies of multiliteracies are relevant for early childhood education. This paper explores these questions in relation to knowledge management initiatives and e-learning opportunities. The Willy Wagtail Tale presents a case study of how knowledge management and e-learning is socially constructed to enrich multiliteracies experiences in the early years. The study occurred in a small Western Australian school committed to the Reggio Emilia teaching approach. Implications for educational research are that multiliteracies experiences occur inadvertently through children's play, are integral to The Hundred Languages of Children, and are dramatically enriched through social constructivist knowledge management and child-centered e-learning.
\end{abstract}

Keywords: Early Childhood, Multiliteracies, E-learning, Knowledge Management, Reggio Emilia.

Biographical notes: Sandra Hesterman is a lecturer in education at Murdoch University, Perth, Western Australia. Her recent research, grounded in postmodern theories, examines how teachers integrate information and communication technologies to enrich students' multiliteracies experiences.

\section{Introduction}

It is argued by Cope and Kalantzis (2000) that $21^{\text {st }}$ century students need to be equipped with skills necessary to meet the challenging and diverse demands of different forms of communication created by new technologies. These skills include the ability to interpret knowledge presented in multimedia communications; to exchange knowledge across a global community; and to generate knowledge. For students to develop competency in each of these skills requires both their use of information and communication technologies (ICT) and also teacher expertise in determining how best to manage students' acquisition of knowledge from multimedia sources. Thus, the ability to read the world, and its global meanings and messages requires skills beyond those of merely reading the word of formalized standardized English. By extension a broader definition of literacy, one that views language as both personal and pluralistic and embraces cultural and linguistic diversity, is now sought to ensure school relevancy beyond the classroom 
door (Loveless, DeVoogd, \& Bohlin, 2001). In the literature this is known as multiliteracies (New London Group, 1996).

How times have changed! The early childhood teacher, at the coalface of education reform, is expected to integrate information and communication technologies in their teaching program to support student literacy in new and dynamic ways (Yelland, 2001). Not only do mandated curriculum documents now include studies of multimodal communications but they still emphasize the importance of learning the conventions of standardized English. Therefore, as debate on the integration of information and communication technologies and the definition of literacy intensifies in the realms of education literature, it falls to early childhood teachers to contemplate practical considerations related to ICT program design and effective pedagogies of multiliteracies. Associated issues include identifying knowledge management practices and e-learning experiences that can build young children's literacy. The use of information and communication technologies in e-learning to provide experiences of multiliteracies in early childhood education (ECE) and accompanying strategies of knowledge management that can support these learning processes remains a seriously underresearched area (Lee, Yelland, O’Rourke, \& Harrison, 2003).

To help fill this gap, this paper examines how e-learning can enrich multiliteracies in the early years when guided by social constructivist knowledge management. The Willy Wagtail Tale presents a classroom account of what these processes looked like in a Western Australian independent community school setting in 2005. At this school, the teachers, although unfamiliar with the term multiliteracies, recognize young students as multiliterate: readers of the world and learning to become readers of the word. These teachers are committed to the Reggio Emilia educational philosophy, which emerged after World War Two in the Reggio Emilia Province in Northern Italy. A theoretical construct aligned with this alternative teaching approach is The Hundred Languages of Children: a paradigm in which there is a myriad of symbolic representations that allow children to communicate and advance their thinking in ways that present language in different forms. This fee-paying school also directs considerable funding to ensure that young students have ready "hands on" access to quality information and communication technologies to support knowledge generation. As this case study will reveal, students are also provided with multiple opportunities to participate in multiliteracies experiences through e-learning. The Willy Wagtail Tale provides insight into one particular teacher's knowledge management practices that supported such learning processes.

Before proceeding to The Willy Wagtail Tale vignette itself, however, it is important that the reader is familiar with related concepts, such as the pedagogy of multiliteracies, multimodal theory, and modes of meaning and also to establish a shared understanding of knowledge management and e-learning. Following this discussion, the relationship of multiliteracies, e-learning, and knowledge management, as depicted in The Willy Wagtail Tale, is explored to show how these three processes were entwined in an early years setting.

\subsection{Pedagogy of Multiliteracies}

The term multiliteracies embraces the notion that there are multiple "modes of representation [that communicate meaning] much broader than language alone" (Cope \& Kalantzis, 2000, p. 5). A pedagogy of multiliteracies "encourages a broader perspective of the student as a learner and values diverse ways of knowing, thinking, doing and being" (O'Rourke, 2005, p. 10). Consequently, critics of traditional school practices argue that the definition of literacy should be broadened to encompass more than 
instructing students on how to master sound-letter correspondence (Geekie, Cambourne, \& Fitzsimmons, 1999). Unsworth (2001) justified this need for change:

In the $21^{\text {st }}$ century the notion of literacy needs to be reconceived as a plurality of literacies and being literate must be seen as anachronistic. As emerging technologies continue to impact on the social construction of these multiple literacies, becoming literate is the more appropriate description (p. 8).

Increasingly, it is claimed that the purpose of teaching literacy in the $21^{\text {st }}$ century is to guide students in learning to read their digital world, "Becoming literate means thinking differently than one previously did, seeing the world differently, and this suggests that there are many different literacies" (Freire, 1972; Papert, 1993, p. 10). A pedagogy of multiliteracies relevant to the early years recognizes students' individual readings of the world and acknowledges that there are multiple modes of meaning in addition to reading the word that can be used to communicate knowledge.

\subsection{Multimodal Theory}

Underpinning a pedagogy of multiliteracies is the multimodal theory that asserts that there is "...multiplicity of ways in which children make meaning...multiplicity of modes, means and materials" for self expression (Kress, 1997, p. 97). From birth, a child seeks to make and understand messages and meanings in accordance with their interests and by using available resources. Having embarked on "their own paths into literacy" long before attending school, children are recognized as multiliterate "thoroughly experienced makers of meaning" who have acquired a myriad of "symbol systems" to voice feelings, perceptions, and thought (Forman \& Fyle, 1998, pp. 248-249; Kress, 1997, pp. 8 \& 97). This theory challenges teachers to reflect critically on how they can provide greater latitude for students' individual expressions of meaning. Exploring representational processes such as "synaesthesia" (association of sensory impression and perceptual experience), "materiality of modes" ("the play of language and image") and "the motivated sign" (the relationship between signs, sign maker, sign making and social context), has the potential to inspire "new curricula of communication" and generate new learning possibilities within e-learning environments (Fleckenstein, Calendrillo, \& Worley, 2002, p. 5; Kress, 2000, p.159).

Along similar lines, the New London Group (1996) argued that the meaning of literacy is represented in many different forms according to its cultural and linguistic context and that a narrow definition of literacy, fails to accommodate this diversity. Thus, a pedagogy of multiliteracies recognizes the need to develop a broader definition of literacy that views language as, "revisionary, creative, personal and pluralistic in nature" (Loveless et al., 2001, p. 74). The different forms of communication created by new technologies also need to be considered when teaching literacy. While a pedagogy of multiliteracies "supplements traditional literacy pedagogy", it also reviews "the multiplicity of communication channels and media" and "increasing salience of cultural and linguistic diversity" by examining different modes of meaning used by individuals to communicate knowledge (Cope \& Kalantzis, 2000, pp. 5 \& 29).

\subsection{Modes of Meaning}

Modes of meaning can be conceptualized as visual, aural, gestural, spatial and linguistic elements of design that can be used in multimodal communications. Table 1 (adapted from Cope \& Kalantzis, 2000) identifies these elements of design. A pedagogy of multiliteracies is based on the idea that to "find our way around mass media, multimedia and electronic hypermedia" and accommodate "the realities of increasing local diversity 
and global connectedness", a new multimodal literacy definition is required (Cope \& Kalantzis, 2000, p. 6). The epistemology underpinning this pedagogy is consistent with constructivist interpretive post-modern theoretical perspectives that view language as "relativist in stance" and knowledge as "relative to time and space" (Patton, 2002, p. 100). Consequently, language and knowledge constructs are subject to individual interpretation at a given point in time and modes of meaning can be varied according to the designer's communication purpose.

Technological innovations have now generated what is described as "knowledge bazaar" (Hsu, 2009), where on-line knowledge is now freely accessible, and open to varied interpretation and change by participants with different life experiences and alternative world views. In the context of e-learning, a pedagogy of multiliteracies, multimodal theory, and multiple modes of meaning, all expand humanity's meaningmaking enterprise, which is the generation of knowledge.

Table 1: Multiliteracies Modes of Meaning

\begin{tabular}{|l|l|}
\hline $\begin{array}{l}\text { Modes of } \\
\text { Meaning }\end{array}$ & Elements of Design \\
\hline $\begin{array}{l}\text { Visual } \\
\text { Designs }\end{array}$ & $\begin{array}{l}\text { Use of colors and line, perspectives, foregrounding, backgrounding, } \\
\text { image, picture, graphic, illustration, chart, diagram, page layouts, } \\
\text { screen formats, costumes, accessories, landscapes etc. }\end{array}$ \\
\hline $\begin{array}{l}\text { Aural } \\
\text { Designs }\end{array}$ & $\begin{array}{l}\text { Music, sound effects, environmental noise: child crying, water } \\
\text { splashing, paper tearing etc. }\end{array}$ \\
\hline $\begin{array}{l}\text { Gestural } \\
\text { Designs }\end{array}$ & $\begin{array}{l}\text { Physical movement, behavior, action, gesture, role playing, drama, } \\
\text { expressions of thought and emotion, demonstration, modeling, sign } \\
\text { language etc. }\end{array}$ \\
\hline $\begin{array}{l}\text { Spatial } \\
\text { Designs }\end{array}$ & $\begin{array}{l}\text { Construction, architecture, space, measurement, distance, distribution, } \\
\text { direction, position, ordering, two- and three-dimensional, geographic } \\
\text { locations, area, horizontal and vertical planes etc. }\end{array}$ \\
\hline $\begin{array}{l}\text { Linguistic } \\
\text { Designs }\end{array}$ & $\begin{array}{l}\text { Oral and written delivery, vocabulary and expression, pronunciation, } \\
\text { metaphors, genres, alphabetic literacy- sound and symbol relationship } \\
\text { etc. }\end{array}$ \\
\hline $\begin{array}{l}\text { Multimodal } \\
\text { Designs }\end{array}$ & $\begin{array}{l}\text { The integrated meaning-making systems of electronic multimedia and } \\
\text { texts; use of computer, interactive whiteboard, digital and video } \\
\text { camera, overhead projector, tape recorder, shadow box, mobile phone } \\
\text { etc. }\end{array}$ \\
\hline
\end{tabular}

\subsection{E-Learning}

Electronic learning (e-learning) is defined as "the use of new multimedia technologies and the Internet to improve the quality of learning by facilitating access to resources and services as well as remote exchanges and collaboration" (European Commission, 2001). This definition "builds upon the tenet that learning is a social process and that e-learning is only a tool, albeit a valuable one, to be used in context with appropriate pedagogical 
practices" (Holmes, 2006, p. 22). Since the 1990s, there has been a proliferation of case study research that documents the capacity of e-learning to leverage "knowledge production, innovation and competitive edge" (Lee, 2005, p. 4). These terms, traditionally associated with business enterprise, now dominate government education policy initiatives and can impact on ECE learning goals:

...we live in a dynamic and rapidly changing world that is driven by forces of competition. There is therefore, an ever growing need to check that knowledge and skill sets that we each have are both relevant to the "time frame" in which we each exist and are appropriate to the jobs and tasks that we have to perform...in principle, we can therefore avoid the confusion, chaos and disaster associated with "not knowing" (Barker, 2005, p. 112).

In the field of education, however, the condition of "not knowing" is not necessarily associated with circumstances of confusion, chaos and disaster. The adage, "as the radius of knowledge extends, the circumference of ignorance expands" is particularly pertinent when considering, "Children starting school this year will be retiring in 2070", and as Robinson (2009) aptly reminded, "No one has any idea of what the world will look like in ten years' time, let alone in 2070" (p. 17). Thus, preparing students for future challenges, it would seem, involves their preparation for multiple ways of knowing. Chalofsky (2005) observed, "In the knowledge era...there are not only multiple ways of viewing reality, but also multiple ways of knowing (learning). Diversity is a stimulant to learning because it forces us to confront different perspectives" (p. 55).

Since the advent of Web 2.0, Australian children are increasingly experiencing new ways of thinking and knowing. Today, ECE teachers are asked to reflect critically on their current practice to consider ways of integrating ICT in their program, and to provide an e-learning environment that inspires emotions of excitement, energy and enthusiasm (Luskin, 2008; Masters, 2004; Yelland \& Masters, 2007).The following e-learning resources can enrich multiliteracies experiences in the early years: live broadcasts, mobile, video and audio telecommunications, two- and three-dimensional electronic graphics, email, and the Web (adapted from Holmes \& Gardner, 2006). The challenge for teachers is to determine: how best to integrate these e-learning resources in their program; and identify knowledge management strategies that best support knowledge generation.

\subsection{Knowledge Management}

In their book, Appreciative Inquiry and Knowledge Management: A Social Constructivist Perspective, Thatchenkery, and Chowdhry (2007) presented a knowledge management (KM) model relevant to the early years. The authors discussed the need for a paradigm shift from knowledge management akin to the banking model, where knowledge is a gift bestowed to the masses by a privileged few, to a model that focuses on knowledgesharing among a community of learners. The authors' understandings were consistent with ECE pedagogical considerations of wanting students to willingly share knowledge derived from lived experiences for the purpose of scaffolding the acquisition of new knowledge. Thatchenkery and Chowdhry (2007) noted, "Since knowledge resides mostly in people's heads, managing it is inherently problematic ...the challenge then is figuring out how to create a knowledge sharing culture" (pp. $1 \& 2$ ).

In ECE, if the individual child is not viewed tabula rasa, an empty vessel to be filled with knowledge, then attention focuses on how teachers can utilize students' acquired knowledge and cultural resources amassed from lived experiences to extend their learning (Harrison, 2005; Pahl \& Rowsell, 2005; Rowsell, 2006). Identified in the literature are three sources of knowledge that can be used to achieve this purpose: 
1. Students' own innate knowledge...mental models, rules, scripts, plans...their private knowledge;

2. Knowledge embedded in an electronic performance support system (emails, the Internet); and

3. The global pool of shared (possibly "public") knowledge that is available to the student as a result of various knowledge-sharing processes (adapted from Barker, 2005, pp. 114 \& 115).

Communication is an essential component of building knowledge. Whether speaking during class discussions, talking on the telephone, conversing by email, or accessing electronic archives, multiple opportunities to scaffold and generate knowledge are presented. A critical consideration for ECE teachers is how best to support knowledge-sharing processes so that students can build on their "private" knowledge.

In the field of corporate business, knowledge is considered a commodity and knowledge management, "a conscious strategy of getting the right knowledge to the right people at the right time" (O'Dell \& Grayson, 1998, p.6). Information and communication technologies are recognized "as a source of innovation", that can maximize opportunities for "knowledge creation, transfer and sharing" in all "key areas of the economy" including education (Bell De Tienne, Dyer, Hoopes, \& Harris, 2004, p. 26; Coonan, 2005, p. 5). There is research, however, that shows that knowledge management involves more than the use of ICT. Kluge, Stein, and Licht (2001) have observed:

To draw the greatest benefits from a knowledge management program and to match best practice, you must enthuse your employees with a desire for knowledge. If a knowledge management measure is to fall on fertile ground... every individual needs to be thirsty for knowledge (p. 25).

If the preceding text is examined through educators' lens, analogies can be made. To draw the greatest benefits from knowledge management, and match best practice in ECE, teachers need to engender a desire for learning. Young children are known to have a "natural curiosity and eagerness to learn", and therefore, it is incumbent upon teachers to provide an environment where students feel inclined to share their knowledge with class peers (Briggs \& Potter, 1999, p. 379). Also significant is how teachers integrate ICT in student learning to support knowledge creation, transfer and sharing in this digital age. As evidenced in The Willy Wagtail Tale, a personal approach to knowledge management, one that focused on humanitarian aspects such as "building confidence and trust", and establishing a collaborative learning environment, where students' knowledge contributions were "openly accepted", were at the very core of effective knowledge management in the early years (Schwarzwalder, 1999, p. 64).

\subsection{Multiliteracies, E-learning and Knowledge Management in the Early Years}

Multiliteracies, e-learning and knowledge management are recognized as powerful mediums in their own right, that can bridge classroom learning to out of school lived experiences in "new and dynamic ways" (Yelland, 2001, p. 3; Yelland, Lee, O'Rourke, \& Harrison, 2008). When these three processes are integrally entwined with constructivist learning theory, however, early years' learning can be enhanced dramatically. Pedagogical considerations include designing an authentic learning environment that accommodates individual student's interests, inspires creative meaning-making designs, promotes cultural and linguistic diversity and broadens literacy definition.

The reader is reminded that ECE has a "long and dynamic history" that has emphasized young students' need for flexible learning environments, the importance of 
play and imagination, and respect for their individual dispositions (Briggs \& Potter, 1999, p. 10). As evidenced in The Willy Wagtail Tale, these enlightenment traditions are revitalized when multiliteracies experiences, e-learning and knowledge management are grounded in a social constructivist conceptual framework.

\section{Research Setting: Bridgewater Community School}

As previously stated, this research was documented in a small Western Australian independent school, now referred to as Bridgewater Community School. Teachers were committed to implementing the Reggio Emilia teaching approach. The school community, while not familiar with multiliteracies conceptual framework, recognized that children learn and communicate in a myriad of "multileveled and multimodal ways" by means of The Hundred Languages of Children (Spaggiari \& Rinaldi, 1996, p. 13).

The term The Hundred Languages of Children is synonymous with the Reggio Emilia teaching approach. It provides a title to an exhibit, a book, a poem, a metaphor, a pedagogy, a theory and a philosophy (Edwards, Gandini, \& Forman, 1998). Each of these forms provides insight to educational principles that underpin this teaching approach. Malaguzzi (1986) who first inspired the idea of The Hundred Languages of Children, aimed to "make visible" the "culture of childhood" through "exchange, reflection and discussion" on early years experiences (Rinaldi, 1998, p. 122; Rinaldi, 2006, p. 59).

To promote The Hundred Languages of Children at Bridgewater Community School (CS), class meetings were held throughout the day, when members listened and were responsive to each other's interests and ideas. The classroom teacher documented meeting dialogue which could extend to thirty minutes, identified knowledge generation, and introduced provocations to further stimulate students' thought. Children were then encouraged, to "take leadership in planning" a child-initiated project that extended their interests and ideas (Katz, 1998, p. 33). They were also encouraged to assume "responsibilities" for their own learning (Edwards et al., 1998, p. 359). To facilitate students' self expression, the teacher ensured that children had ready access to a diverse range of open-ended resources that could be used to communicate their knowledge and understandings, and explore further their developing theories.

Teachers adopting the Reggio Emilia teaching approach recognize children as "unique individuals with rights", who are "rich in resources, strong and competent" (Rinaldi, 1998, p. 114). Described as "a new paradigm for the sociology of childhood", young students are perceived as "authors and inventors", "who know how to walk along the path of understanding", and who are "protagonists of their own growth" (Malaguzzi, 1998, pp. 67 \& 180; Nimmo, 1998, p. 306). Reflective pedagogy is considered critical to teachers' successful implementation of the Reggio Emilia teaching approach.

At Bridgewater CS, there was also a high level of school community interest and commitment to integrating ICT in students' learning. An Information Technology (IT) specialist was employed to support teachers and students' interest in integrating ICT in class projects. The school's budget also provided generous funding to provide a diverse range of quality ICT resources for class use. Consequently, information and communication technologies were not considered "precious" resources. They were freely accessed by students in the same manner as other regular classroom resources, such as adhesive tape and colored pencils. ICT were tools to be used when they served a purpose.

The Willy Wagtail Tale documented a pre-primary class project over a four month period and employed ethnographic methodology. Participant observations, semi 
structured interviews, and document and video analysis were methods used to retell this amazing tale. Class members included 17 students aged between five and six years, an early childhood teacher (pseudonym Whitney) and one teacher assistant. The involvement of a Bridgewater CS IT specialist (pseudonym Jon) in the class project was also recorded. In this early years' setting there were multiple opportunities for students' hands on experiences to design personal meaning and express cultural and linguistic diversity using a wide range of resources. Throughout the school year, ICT was used to enrich students' multiliteracies experiences, during short and long-term child-initiated, teacher facilitated, and open-ended project investigations.

\subsection{Case Study Vignette: The Willy Wagtail Tale}

In August 2005, Whitney's students pulled chairs into an enclosed patio area adjacent to their classroom for a morning meeting. The patio area could be viewed through a large classroom window. During the previous week, much to everyone's surprise and delight two willy wagtails commenced flying through the patio area, their loud communications interrupting conversation. The children listened and imitated the birds' aural designs, their whistling, chirping, and singing. They compared these sounds to other bird noises they had heard when visiting the parkland lake near their school.

One student suggested to the class that they suspend a branch from the patio eaves so the birds had a place to rest. Others agreed this was a good idea and Whitney facilitated the design process. The next day, two students decided the birds might like ready-made nests. They decorated two small plastic containers and asked Whitney to attach these to the branch. Another teacher walking by, called out, "Don't be silly. They [the birds] won't come!"

After the weekend, the class returned to school to discover, as if by magic, two birds building a nest on the suspended branch (Figure 1). Students offered the birds some blue woolen threads as decorative nesting material. The wind blew the wool under a chair and it was soon forgotten.

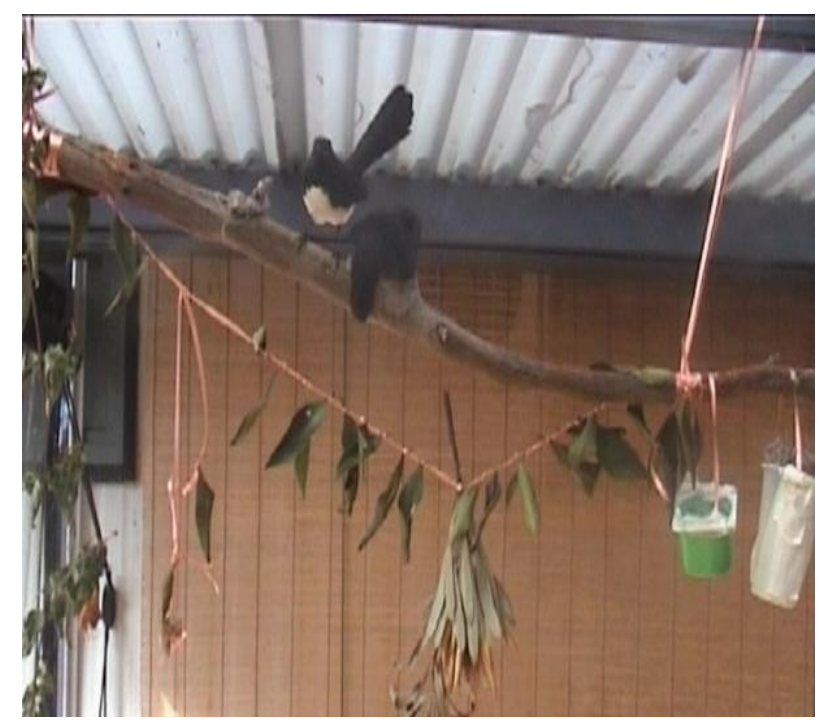

Figure 1. Willy Wagtails under the Patio Eaves 
To support students' interest in the birds, Whitney recorded the nest building by positioning a video camera high on a stack of milk crates, leveled at nest height. Children now focused their attention on the birds' gestures and flight patterns hoping to discover where the birds ventured after leaving the patio area. Viewing the video images on a laptop, the class observed the birds' faces masked with cobwebs and noted the skilful smearing motions used to create a neat cup-shaped nest. One week and many hours of video footage later the nest was completed and the birds took turns to sit. Students had many questions. They wondered what the nest is made of, how many eggs there might be, which bird was the "mum" or "dad". The children wanted to climb high and see what was in the nest.

Whitney decided to suspend an Isight camera from the eaves just above the nest. The IT specialist, Jon, provided the necessary equipment. Whitney linked the camera connection to her laptop that was inside the classroom. There was immense class excitement as three eggs were viewed along with the blue wool woven into the nest lining.

Outside in the patio area, the children observed the birds' activities and the nest from different perspectives, side profile and beneath (Figure 2). Inside the classroom, they observed nest features from an aerial perspective. The children discussed differences in visual, spatial and gestural designs.

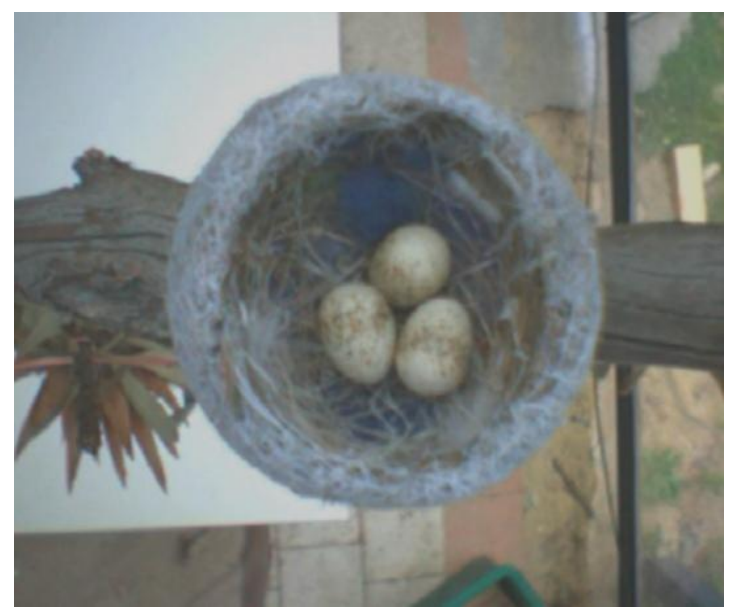

Figure 2. Aerial Perspective of the Nest

They also learned that if they stood directly beneath the nest an aerial view of their body was also captured on video and viewed on the laptop screen. Peers inside the classroom called out enthusiastically through the large window, "We can see you!" Students took turns performing different gestural designs under the nest to be captured on video or stayed inside the classroom viewing the computer screen to provide peer feedback. They eagerly tallied the number of times the adults sat on the eggs.

A parent contacted The Western Australian newspaper and a reporter visited the school. Children theorized how they would become rich and famous. Due to the publicity, the school was contacted by bird enthusiasts in the wider community who were interested to learn the latest "bird news".

With the help from another parent, a webcam was connected to Whitney's laptop so the birds could be viewed by others on the Intranet and Internet (Figures 2-4). Children enquired about the nest-building materials. The school community soon accessed the 
World Wide Web. Information and clarification was sought from local ornithologists by email.

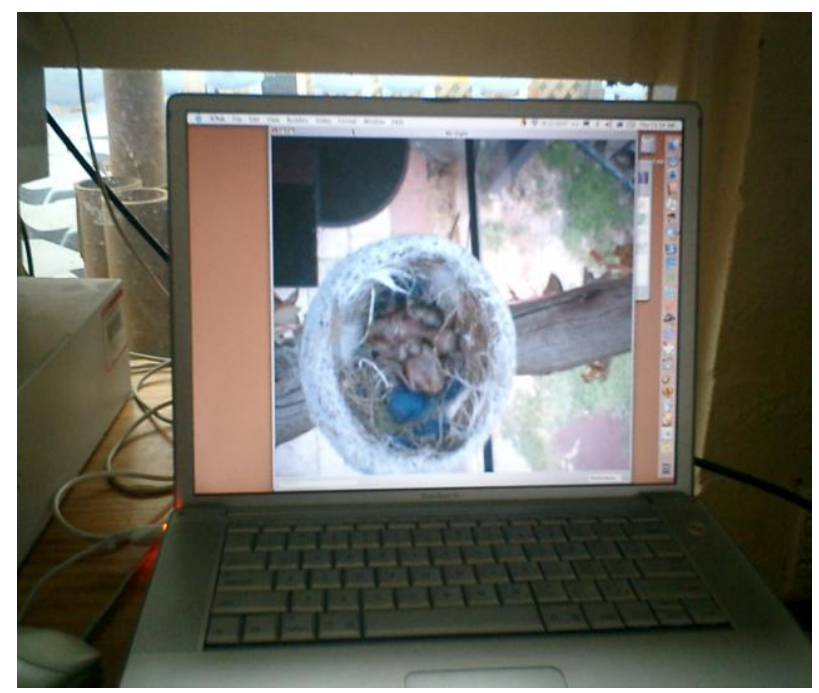

Figure 3. Nest Activities Communications via the Intranet and Internet

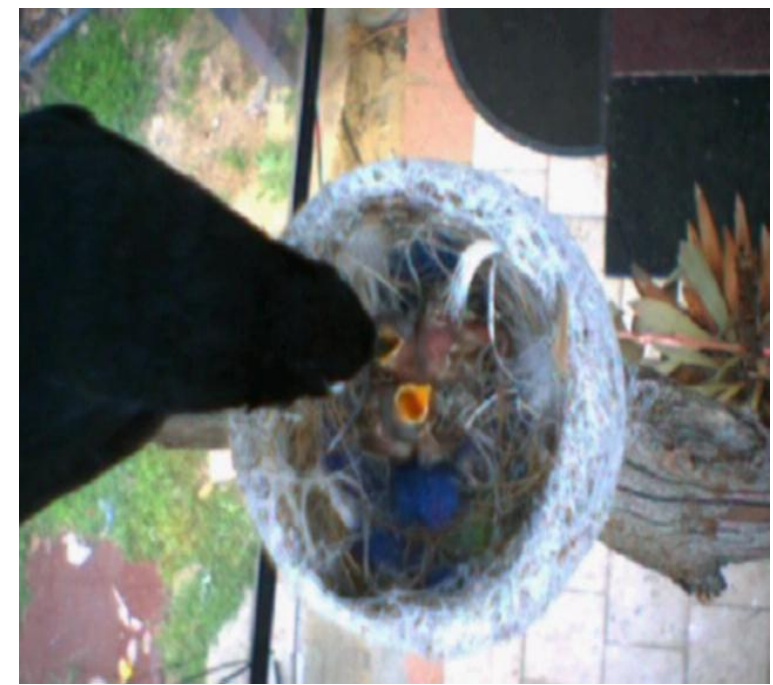

Figure 4. Video Image of Adult Birds Feeding Hatchlings

Children spontaneously drew visual designs of nest images and theorized about the birds' appearance inside the eggs. To support this process, Whitney provided her students with a black and white digital image of the eggs and encouraged them to superimpose their visual design onto paper (Figure 5). One-week later, one egg disappeared from the nest and children theorized where it had gone. The students learned from the wider community that the cup shaped nest was constructed from beak smeared spider webs and that it was near impossible to distinguish a male from a female willy wagtail. 


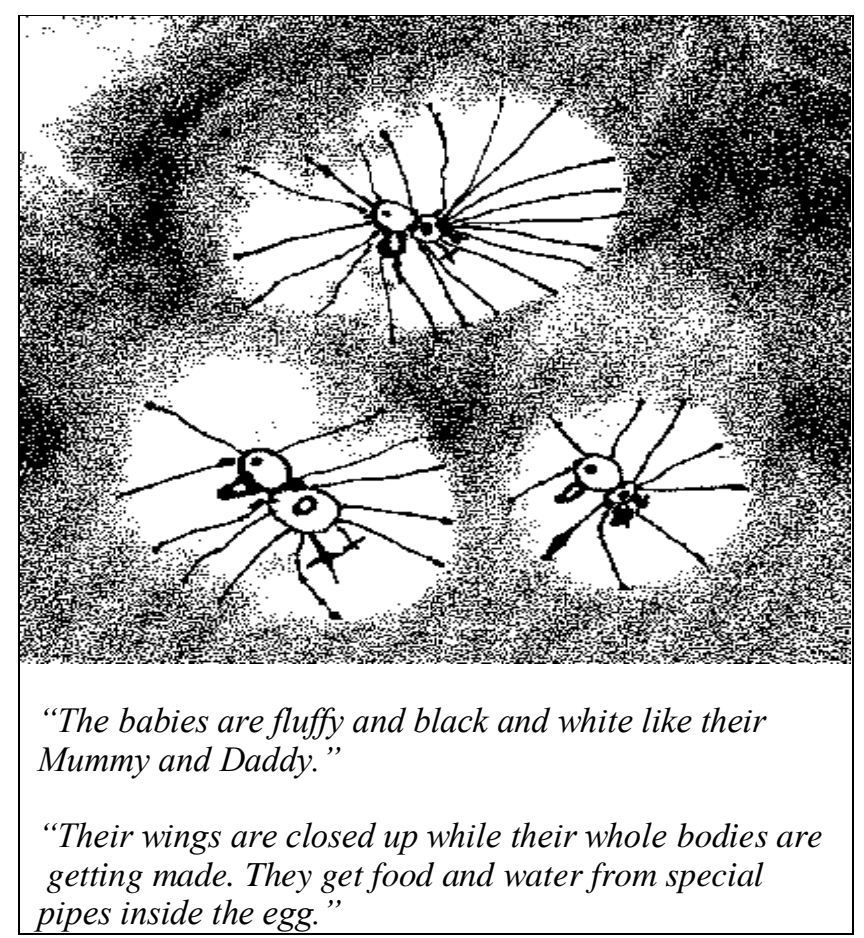

Figure 5. Students Theories and Draw "Baby Birds" Appearance inside the Eggs

The next day the other two eggs hatched. Students observed the adult birds feeding their young, the hatchlings' diet and the dramatic change in bird appearance. Class meetings focused on how the "baby birds" had the same needs as children: care, food, and shelter. Children theorized how the images from the laptop were transported to other computers (Figure 6).

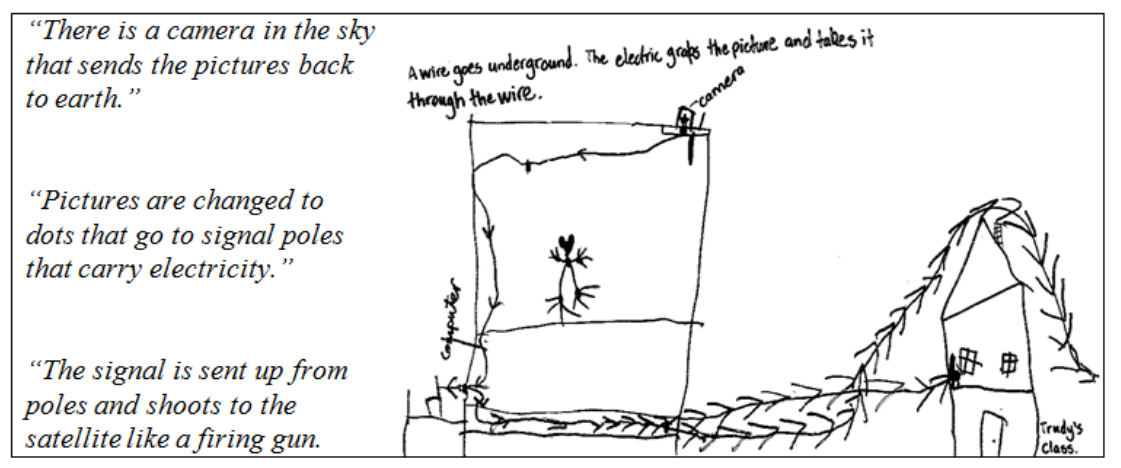

\section{Figure 6. Students Theories How Screen Images Travel between Computers}

To further extend children's interest in the birds' activities, Whitney linked her laptop to a data projector. Birds and nest images were then displayed onto a white classroom wall. The children observed and then initiated gestures imitating bird movement. They designed play scripts with the intention of presenting a bird show to others. They talked to the bird images on the wall, stroked their projected bodies and patted the egg shapes. After the eggs hatched, the children role-played feeding the 
hatchlings and imitated their different calls. They interacted spontaneously through free play and initiated a wide range of visual, aural, gestural, spatial, linguistic and multimodal modes of meaning.

After the school holidays, the children returned to discover the fledglings had left the nest but were still flying close to the classroom. The children searched for the young birds' new home and asked, "Do they have their own nest?" Connections with "leaving the nest" were made with students' own life experiences, such as leaving the school at the end of the year, or selling the family home. A group of students sought natural materials to design their own bird nests then photographed these using a digital camera (Figures 7 and 8). Whitney advised students she knew someone else who did work like them and presented them with the visual designs, produced by British sculptor, photographer and environmentalist, Andy Goldsworthy (1990).

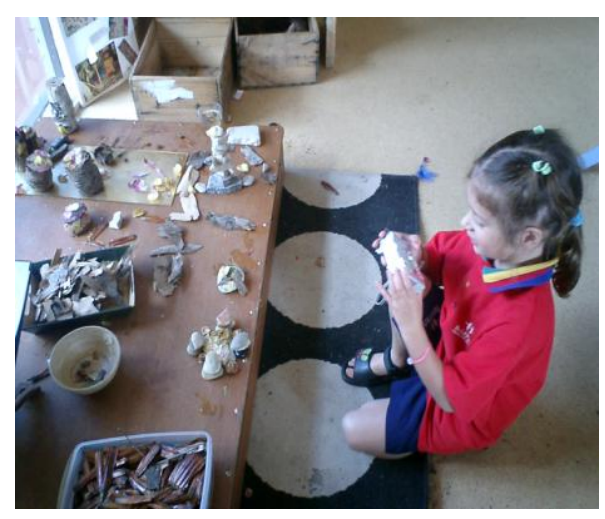

Figure 7. Integrating ICT
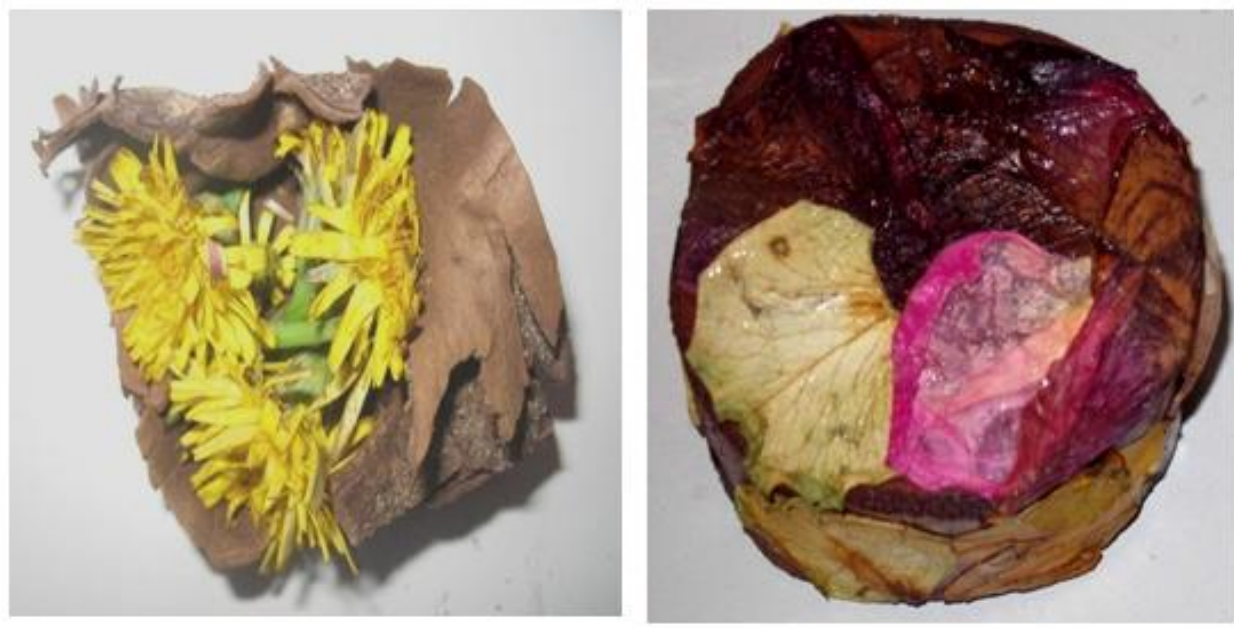

Figures 8a \& 8b: Digitalizing Nest Designs

As the end of the school year drew close, Whitney edited long lengths of video footage to produce a DVD student keepsake. She included her own reflections on this project experience: 
A child's dream became a reality as we watched with pleasure and wonderment as the birds built their nest and raised their young. It has been an amazing opportunity to document the life of the willy wagtails and has created opportunities to interconnect and build relationships throughout the school and the wider community.

The case study vignette of The Willy Wagtail Tale illustrated how Whitney integrated ICT to promote The Hundred Languages of Children and in so doing provided extensive opportunities to enrich multiliteracies experiences. This early year's class project accommodated students' interests and inspired creative designs employing visual, aural, gestural, spatial, linguistic, and multimodal modes of meaning. Whitney's social constructivist knowledge management practices and provision of a child-centered elearning environment were critical in supporting these processes.

\subsection{Project Postscript}

Whitney's program design facilitated students' active involvement in daily project investigations that emanated from their natural curiosity and eagerness to learn. In The Willy Wagtail Tale project, students' interest in the birds continued until the end of the school year. During the following school year, numerous willy wagtails were seen perching in nearby trees (Figure 9) and occasionally they visited the classroom patio area to chirp morning greetings. The children shared the tale of the willy wagtails with new students. All hoped a second nest would be built.

As previously stated, The Willy Wagtail Tale presented an exemplar of ICT integration in the early years that supported multiliteracies experiences and included elearning. The vignette also demonstrated how knowledge management enriched "constructive solution" to inquiry-based learning and promoted community "discourse, interactivity and communication" far beyond the early year's classroom (Almala, 2005, p. 10; Almala, 2006, p. 33).

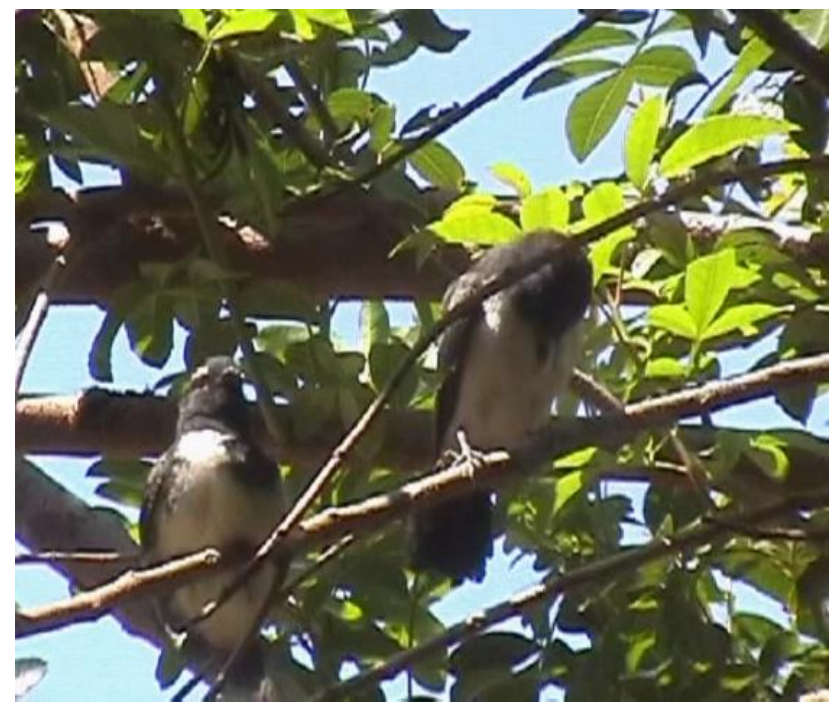

Figure 9. Fledglings Remaining Close to the Classroom Patio Area 


\section{Discussion}

Perhaps the most powerful insight into Whitney's knowledge management practices and e-learning considerations was provided when she described her pedagogy as fundamentally "social constructivist" and said that the Reggio Emilia teaching approach to ECE provided the best example of its principles in action. The Reggio Emilia teaching approach, shaped by the writings of Dewey, Montessori, Piaget, Vygotsky, Bruner, Gardner, and Malaguzzi, promotes social constructivist learning principles, "the idea that knowledge is socially constructed in a cultural setting" (Hill, Stremmel, \& Fu, 2005, p. 7) and that "there is no knowledge independent of the meaning attributed to experience (constructed) by the learner, or community of learners" (Hein, 1991, p. 1). These principles are integrated in curriculum design. Thus, rather than teacher pre-planned, it is "negotiated" through "emergent processes between adults and children" (Pope Edwards, 2002 , p. 4). It is opportunities for negotiation through emergent curriculum that enable teachers and students to explore new literacies and use ICT to learn in new ways.

Whitney stated that, at Bridgewater CS, the "social component" of social constructivism occurred when class members learned how to form a group, listen carefully, challenge ideas, and scaffold one another's learning within a group setting.

Whitney designed an ECE program that involved daily class meetings that provided a forum for children to ask questions about project investigations. Projects remained broad-based and open-ended to enable students to determine the direction and duration of their study. Class meetings occurred three times a day and could last up to an hour. Whitney commented, "These meetings give children opportunities to reflect on new understandings, to share problems, clarify thoughts, and to search for relationships, where theories are constructed, inconsistencies questioned, and theories repaired." Clearly demonstrated in The Willy Wagtail Tale, were Whitney's social constructivist knowledge management strategies. Students' interests were accommodated and cultural and linguistic diversity was embraced. Both of these are essential prerequisites if multiliteracies experiences are to be enriched in the early years.

Whitney's e-learning pedagogical considerations included adopting a broad ICT definition, and facilitating students' daily access to ICT resources in response to their meaning-making design requests. She ensured that there was time, space and resources for students to share their ICT hands on experiences and multiliteracies expressions with interested others. Transforming Whitney's pedagogical considerations into practice, however, was dependent on having a school community committed to providing students with extensive exposure to different modes of communication, namely The Hundred Languages of Children. At Bridgewater CS, the community shared a common bond to support the integration of ICT for the purpose of exploring diverse learning possibilities. ICT was used to share students' discoveries, knowledge and understanding with members of the wider community.

During an interview, Whitney explained that she was "passionate" about using computers, "loved" to experiment with their creative applications and "thrilled" when children were excited about their own ICT discoveries. Clearly, Whitney was highly motivated to provide a classroom environment that "engaged and empowered eLearners" (Donohue, Fox, \& Torrence, 2007, p. 35). She reflected critically about how different resources, including ICT, could be used to support students' individual symbolic representations of knowledge, as derived from their life experiences. Whitney's knowledge management practices were consistent with those of post-modern thinkers who believe that "truth, reality and knowledge are always changing and constructed by human beings in multiple forms" (Cannella, 1997, p. 13). Whitney's program provided 
extensive time and multiple opportunities for students' hands-on play experiences to design personal meaning using a wide range of ICT resources.

\section{Conclusion}

The Willy Wagtail Tale relays a simple story, at its core, a teacher's responsiveness to accommodate a student's request to hang a branch under patio eaves for birds to rest. The amazing events that unfolded and the extensive multiliteracies experiences that were offered to students as a result, would not have occurred, except for the teacher's commitment to support emergent curriculum, integrate ICT, and promote The Hundred Languages of Children. Pedagogical considerations that enriched multiliteracies experiences included how to provide opportunities for students' e-learning and implement knowledge management strategies that extended students' individual meaning-making designs.

During the four month project, community relationships were fostered, students' interests were accommodated, creative designs were inspired, and cultural and linguistic diversity was empowered. Questions such as, "What will new literacies look like in an early years program?", "How can ICT be used to learn in new ways?", and "What pedagogies of multiliteracies are relevant for early childhood education?" were explored. Perhaps of most interest to early childhood teachers at the coalface of education reform, is that enriching early years' multiliteracies experiences as depicted in The Willy Wagtail Tale, occurred inadvertently through social constructivist knowledge management and child-centered e-learning.

\section{References}

1 Almala, A. H. (2005). A constructivist conceptual framework for a quality e-learning environment. Distance Learning, 2(5), 9-12.

2 Almala, A. H. (2006). Applying the principles of constructivism to a quality elearning environment. Distance Education, 3(1), 33-40.

3 Barker, P. (2005). Knowledge management for e-learning. Innovations in Education and Teaching International, 42(2), 111-121.

4 Bell De Tienne, K., Dyer, G., Hoopes, C., \& Harris, S. (2004). Toward a model of effective knowledge management and directions for future research: Culture, leadership, and CKOs. Journal of Leadership \& Organizational Studies, 10(4), 2644.

5 Briggs, F., \& Potter, G. (1999). The early years of school. Sydney: Longman.

6 Cannella, G. S. (1997). Deconstructing early childhood education. New York: Peter Lang Publishing, Inc.

7 Chalofsky, N. (2005). Reshaping the way we view the world. ProQuest Educational Journal, 5(11), 54-58.

8 Coonan, H. (2005). Address to the 2005 ICT outlook forum. Paper presented at the Creating Competitive Advantage from ICT, Sydney.

9 Cope, B., \& Kalantzis, M. (Eds.). (2000). Multiliteracies: Literacies learning and the design of social futures. South Yarra: Macmillan.

10 Donohue, C., Fox, S., \& Terrence, D. (2007). Early childhood educators as e-learners: Engaging approaches to teaching and learning. Young Children, July, 34-39. 
11 Edwards, S., Gandini, L., \& Forman, G. (Eds.). (1998). The hundred languages of children. Greenwich: Ablex Publishing Corporation.

12 European Commission. (2001). Communication to the Council and the European Parliament: The e-learning action plan, designing tomorrow's education. In U. Ehlers \& J. M. Pawlowski (Eds.), Handbook on quality and standardisation in elearning. Heidelberg: Springer Berlin.

13 Fleckenstein, K. S., Calendrillo, L. T., \& Worley D. A. (Eds.). (2002) Language and image in the reading-writing classroom: Teaching vision. Mahwah, N.J.: Lawrence Erlbaum Associates Inc.

14 Forman, G., \& Fyle, B. (1998). Negotiated learning through design, documentation, and discourse. In C. Edwards, L. Gandini, \& G. Forman (Eds.), The hundred languages of children: The Reggio Emilia approach - Advanced reflections ( $\mathrm{pp}$. 239-250). Greenwich: Ablex Publishing Corporation.

15 Freire, P. (1972). Pedagogy of the oppressed. New York: Herder and Herder.

16 Geekie, P., Cambourne, B., \& Fitzsimmons, P. (1999). Understanding literacy development. Stoke-on-Trent: Trentham.

17 Goldsworthy, A. (1990). Andy Goldsworthy. London: Penguin.

18 Harrison, C. (2005). Young gifted children: Their search for complexity and connection. Exeter: INSCRIPT Publishing.

19 Hein, G. (1991). Constructivist learning theory. Paper presented at The Museum and the Needs of People, CECA Conference, Jerusalem, Israel.

20 Hill, L. T., Stremmel, A. J., \& Fu, V. R. (2005). Teaching as inquiry: Rethinking curriculum in early childhood education. Boston: Pearson Education, Inc.

21 Holmes, B. (2006). Quality in a Europe of diverse systems and shared goals In U. Ehlers \& J. M. Pawlowski (Eds.), Handbook on quality and standardisation in elearning. Heidelberg: Springer Berlin.

22 Holmes, B., \& Gardner, J. (2006). E-learning concepts and practice. Thousand Oaks: Sage Publications.

23 Hsu, J. (2009). Innovative technologies for education and learning: Education and knowledge- orientated blogs, wikis, podcasts, and more. In E. J. Szewczak (Ed.), Selected readings on the human side of information technology (pp. 203-223). New York: Information Science Reference.

24 Katz, L. G. (1998). What can we learn from Reggio Emilia? In S. Edwards, L. Gandini, \& G. Forman (Eds.), The hundred languages of children: The Reggio Emilia approach - Advanced reflections. Greenwich, CT: Ablex Publishing Corporation.

25 Kluge, J., Stein, W., \& Licht, T. (2001). Knowledge unplugged: The McKinsey \& Company global survey on knowledge management. New York: Palgrave Macmillan.

26 Kress, G. (1997). Before writing: Rethinking the paths to literacy. London: Routledge.

27 Kress, G. (2000). Design and transformation. In B. Cope \& M. Kalantzis (Eds.), Multiliteracies: Literacy learning and design of social futures. South Yarra: Macmillan.

28 Lee, A. (2005). Knowing our business: The role of education in the university. Canberra: Australian Council of Deans of Education. 
29 Lee, L., Yelland, N., O’Rourke, M., \& Harrison, C. (2003). A pedagogy for multiliteracies with information and communication technologies in early childhood education: Australian research grant application. Perth: Murdoch University.

30 Loveless, A., DeVoogd, G., \& Bohlin, R. (2001). Something old, something new...: Is pedagogy affected by ICT? In A. Loveless \& V. Ellis (Eds.), ICT, pedagogy and the curriculum: Subject to change (pp. 63-83). London: Routledge Falmer.

31 Luskin, B. (2008). Internet Media Solutions. Retrieved June 16, 2009, from Luskin International Web Site: http://www.internetmedia-solutions.com/eng/e-learning.php

32 Malaguzzi, L. (1986). The hundred languages of children: Catalogue of the exhibition. Reggio Emilia: Reggio Emilia Children.

33 Malaguzzi, L. (1998). History, ideas, and basic philosophy: An interview with Lella Gandini. In C. Edwards, L. Gandini, \& G. Forman (Eds.), The hundred languages of children: The Reggio Emilia approach - Advanced reflections (pp. 49-97). Greenwich: Ablex Publishing Corporation.

34 Masters, J. (2004). Realising the potential of computers in the classroom: Teacher scaffolding strategies for supporting children working with computers. Paper presented at the Reform and Realise the Potential Conference, Adelaide, Australia: ACCE.

35 New London Group (1996). A pedagogy of multiliteracies: Designing social futures. Harvard Educational Review, 66(1), 60-93.

36 Nimmo, J. (1998). The child in community: Constraints from the early childhood lore. In S. Edwards, L. Gandini, \& G. Forman (Eds.), The Reggio Emilia approach: Advanced reflections (pp. 295-312). London: Ablex Publishing Corporation.

37 O'Dell, C., \& Grayson, C. J. Jr. (1998). If we only knew what we know: The transfer of internal knowledge and best practice. New York: The Free Press.

38 O'Rourke, M. (2005). Multiliteracies for 21st century schools. In ANSN (Ed.), Snapshot. Lindfield, NSW: The Australian National Schools Network Ltd.

39 Pahl, K., \& Rowsell, J. (2005). Literacy and education: Understanding the new literacy studies in the classroom. London: Paul Chapman Publishing.

40 Papert, S. (1993). The children's machine: Rethinking school in the age of the computer. New York: Basic Books.

41 Patton, M. Q. (2002). Qualitative research \& evaluation methods (3rd ed.). Thousand Oaks, CA: Sage Publications.

42 Pope Edwards, C. (2002). Three approaches from Europe: Waldorf, Montessori and ReggioEmilia. Early Childhood Research and Practice, 4(1).

43 Rinaldi, C. (1998). Projected curriculum constructed through documentation progettazione: An interview with Lella Gandini. In C. Edwards, L. Gandini, \& G. Forman (Eds.), The hundred languages of children: The Reggio Emilia approach Advanced reflections. Greenwich, CT: Ablex Publishing Corporation.

44 Rinaldi, C. (2006). In dialogue with Reggio Emilia. New York: Routledge.

45 Robinson, K. (2009). The element: How finding your passion changes everything. Maryborough, Victoria: Allen Lane.

46 Rowsell, J. (2006). Family literacy experiences: Creating reading and writing opportunities that support classroom learning. Markham, Ontario: Pembroke.

47 Schwarzwalder, R. (1999). Librarians as knowledge management agents. EContent, 2(4), 63-65. 
48 Spaggiari, S., \& Rinaldi, C. (1996). I centro linguaggi dei bambini: Narrativa del possible. Reggio Emilia: Reggio Children.

49 Thatchenkery, T., \& Chowdhry, D. (2007) Appreciative inquiry and knowledge management: A social constructivist perspective. Cheltenham: Edward Elgar Publishing Ltd.

50 Unsworth, L. (2001). Teaching multiliteracies across the curriculum: Changing contexts of text and image in classroom practice. Buckingham: Open University Press.

51 Yelland, N. (2001). Teaching and learning with information and communication technologies (ICT) for numeracy in the early childhood and primary years of schooling: A Report prepared for: Research and Evaluation Branch, International Analysis and Evaluation Division, Department of Education, Training and Youth Affairs.

52 Yelland, N., \& Masters, J. (2007). Rethinking scaffolding in the information age. Computers and Education, 48(3), 362-382.

53 Yelland, N., Lee, L., O’Rourke, M., \& Harrison, C. (2008). Rethinking learning in early childhood. Maidenhead: Open University Press. 